\title{
Evaluasi Produktivitas Beberapa Varietas Padi
}

\section{Evaluation of Productivity on Several Varieties of Rice}

\author{
Asep Hambali, Iskandar Lubis* \\ Departemen Agronomi dan Hortikultura, Fakultas Pertanian, Institut Pertanian Bogor \\ (Bogor Agricultural University), Jl. Meranti, Kampus IPB Darmaga, Bogor 16680, Indonesia \\ Telp.\&Faks.62-251-8629353 e-mail agronipb@indo.net.id \\ *Penulis untuk korespondensi: iskandarlbs@yahoo.com
}

Disetujui 11 Mei 2015 /Published online 18 Mei 2015

\begin{abstract}
The research was conducted on February to June 2014 in Muara Rice Research Institute, Bogor. The purpose of this study was to determine the factors that affect the productivity some of rices varieties. The design used was a randomized complete design group with one factor consists of 6 varieties. The varieties used are new varieties (varieties Inpari 13, Ciherang, Mekongga), a new type of rice (IPB 4S), local variety (Mentik Wangi), and hybrid variety (Hipa Jatim 2). Each variety was repeated three times to be 18 experimental units. The results showed that in general, high yielding varieties (VUB) Inpari 13, Ciherang and Mekongga have higher productivity than other varieties (local, PTB, hybrid). VUB Productivity ranged from 4.59 to 5.62 tons per hectare. The results of the three VUB productivity was influenced by yield components such as number of productive tillers, 1000 grain weight, percentage of filled grain and resistance to pests and diseases.
\end{abstract}

Keywords: productivity, result component, rice varieties

\begin{abstract}
ABSTRAK
Penelitian ini berlangsung pada bulan Februari sampai Juni 2014 dan dilaksanakan di Balai Penelitian Padi Muara, Bogor. Tujuan dari penelitian ini adalah untuk mempelajari faktor-faktor tanaman yang mempengaruhi produktivitas beberapa varietas padi. Rancangan yang digunakan adalah rancangan kelompok lengkap teracak (RKLT) dengan satu faktor yaitu varietas yang terdiri dari 6 varietas. Varietas yang digunakan adalah varietas unggul baru (varietas Inpari 13, Ciherang, Mekongga), padi tipe baru (IPB $4 S$ ), varietas lokal (Mentik Wangi), dan varietas hibrida (Hipa Jatim 2). Masing-masing varietas diulang sebanyak tiga kali sehingga terbentuk 18 satuan percobaan. Hasil penelitian menunjukkan bahwa secara umum varietas unggul (VUB) Inpari 13, Ciherang dan Mekongga memiliki produktivitas lebih tinggi dari varietas yang lain (lokal, PTB, hibrida). Produktivitas VUB berkisar antara 4.59 hingga 5.62 ton ha'. . Hasil produktivitas ketiga VUB ini dipengaruhi oleh komponen hasilnya yaitu anakan produktif, bobot 1000 butir, persentase gabah isi dan ketahanan terhadap hama penyakit.
\end{abstract}

Kata kunci : komponen hasil, produktivitas, varietas padi 


\section{PENDAHULUAN}

Penduduk Indonesia merupakan penduduk dengan konsumsi beras yang cukup tinggi. Menurut Deptan (2011) konsumsi beras Indonesia lebih besar dibandingkan Malaysia dan Thailand yang hanya berkisar $65 \mathrm{~kg}$ dan $70 \mathrm{~kg}$ kapita $^{-1}$ tahun $^{-1}$. Deptan (2013) menyatakan bahwa konsumsi beras di Indonesia mencapai $139 \mathrm{~kg}$ kapita $^{-1}$ tahun $^{-1}$ jauh melebihi rata-rata tingkat konsumsi dunia yaitu $60 \mathrm{~kg}$ kapita $^{-1}$ tahun $^{-1}$. Berdasarkan data BPS (2013) produksi padi Indonesia pada tahun 2013 mencapai 71279709 ton dengan luas panen 13835252 ha dan produktivitas nasional 5.152 ton $\mathrm{ha}^{-1}$. Angka impor beras Indonesia masih tinggi, pada tahun 2011 sebesar 2750476 ton, tahun 2012 sebesar 1 810372 ton dan tahun 2013 sebesar 472664 ton (BPS, 2014).

Strategi yang ditempuh dalam rangka peningkatan produksi adalah peningkatan produktivitas padi, perluasan areal padi sawah, dan pengelolaan lahan. Peningkatan produktivitas dapat dilakukan diantaranya dengan mengunakan bibit dari varietas unggul. Selama kurun waktu 30 tahun sejak 1970-an, kontribusi peningkatan produktivitas padi dengan penanaman varietas unggul terhadap produksi padi nasional mencapai $56.1 \%$, lebih besar dibanding kontribusi perluasan areal lahan yang hanya 26.3\% (Las et al., 2004). Penanaman varietas unggul berdaya hasil tinggi sangat diandalkan dalam peningkatan produktivitas. Varietas unggul padi memiliki sifat yaitu berdaya hasil tinggi, tahan terhadap hama dan penyakit, umur genjah, dan rasa pulen (Suprihatno et al., 2009).

Varietas merupakan salah satu komponen penting yang berkontribusi dalam peningkatkan produksi dan produktivitas padi. Banyaknya varietas unggul yang dilepas, dapat dijadikan alternatif pilihan bagi petani memilih varietas yang sesuai dengan kondisi agroklimatnya (Minarsih et al., 2013). Sejak penelitian padi tahun 1943 hingga 2006 telah dilepas 189 varietas padi. Dalam periode 2000 - 2006, Badan Litbang Pertanian telah melepas 59 varietas unggul padi, 43 varietas untuk lahan sawah irigasi, 5 varietas padi gogo, dan 9 varietas padi pasang surut (Sembiring, 2007). Oleh karena itu, perlu upaya intensif mensosialisasikan varietas-varietas tersebut secara lebih luas kepada masyarakat.

Indonesia memiliki beragam tipe-tipe padi dan masing-masing memiliki karakter serta produktivitas yang berbeda. Menurut Zein et al. (2002) faktor yang menuntukan produktivitas padi adalah faktor vegetatif dan generatif, karakter agronomi serta komponen hasil yang mempengaruhinya. Perbedaan hasil pada padi dipengaruhi oleh kemampuan tanaman dalam mentranslokasikan asimilat selama pengisian biji dan mengakumulasi bahan kering sebelum heading (Miah et al., 1996). Berdasarkan hal tersebut penelitian ini perlu dilakukan untuk mengkaji beberapa varietas padi terhadap pertumbuhan dan produksi untuk mendapatkan varietas yang dapat beradaptasi baik dan dapat dipelajari faktor-faktor tanaman yang mempengaruhi produktivitasnya.

\section{BAHAN DAN METODE}

Penelitian dilakukan di lahan percobaan Balai Penelitian Padi Muara, Bogor, Jawa Barat terletak pada ketinggian $250 \mathrm{~m}$ dpl dengan jenis tanah latosol. Penelitian dilaksanakan pada bulan Februari hingga bulan Juni 2014. Bahan yang digunakan adalah 3 varietas padi sawah unggul baru (VUB), 1 varietas tipe baru (PTB), 1 varietas hibrida, dan 1 varietas lokal. Varietas yang digunakan adalah Inpari 13, Ciherang, Mekongga (VUB), IPB 4S (PTB), Mentik Wangi (Varietas Lokal), Hipa Jatim (Varietas Hibrida). Pupuk yang digunakan yaitu pupuk urea $\left(250 \mathrm{~kg} \mathrm{ha}^{-1}\right)$, pupuk SP-36 (150 kg ha-1), pupuk KCl (150 kg ha$\left.{ }^{1}\right)$, Phonska (300 kg ha $\left.{ }^{-1}\right)$ dan pestisida jika terjadi serangan hama dan penyakit. Alat yang akan digunakan adalah hand tractor, cangkul, garu, sabit, meteran, soil plant analysis development (SPAD), moisture tester, knapshake sprayer, alat panen dan mesin perontok padi.

Pengolahan tanah dilakukan dengan traktor. Sebagian lahan digunakan sebagai tempat persemaian. Pemupukan dilakukan pada saat bibit berumur 5 hari setelah semai (HSS) dengan pupuk urea $10 \mathrm{~g} \mathrm{~m}^{-2}$. Bibit dipindah tanam setelah berumur 21 HSS pada petak berukuran $5 \mathrm{~m} \times 5 \mathrm{~m}$. Jumlah bibit per lubang tanam yaitu tiga bibit dengan jarak tanam $25 \mathrm{~cm} \times 25 \mathrm{~cm}$. Penyulaman dilakukan pada saat tanaman berumur 7-10 hari setelah tanam (HST). Pemupukan tanaman dilakukan sebanyak tiga kali. Pemupukan pertama dilakukan saat tanaman berumur 10 HST, pemupukan kedua saat tanaman berumur 4 minggu setelah tanam (MST), dan pemupukan ketiga saat tanaman berumur 6 MST. Pupuk SP36 dan $\mathrm{KCl}$ diberikan seluruhnya pada pemupukan pertama sedangkan pupuk Urea diberikan tiga kali. Pemeliharaan meliputi pengambilan keong mas, penyiangan gulma, pengaturan air, dan pengendalian hama penyakit tanaman. Pemanenan dimulai ketika malai telah menguning kurang lebih 90\%. Pemanenan 
dilakukan dengan menggunakan arit/sabit. Padi yang telah dipanen kemudian dirontok dengan cara dibanting dan menggunakan alat perontok sederhana.

Pengamatan dilakukan pada 10 tanaman contoh per petak dengan komponen yang diamati meliputi :

1. Tinggi tanaman diukur dari permukaan tanah hingga ujung daun tertinggi yang diamati mulai 3 MST hingga 8 MST dengan menggunakan meteran.

2. Jumlah anakan yang diamati mulai 3 MST sampai 8 MST.

3. Jumlah anakan total dan anakan produktif yang dihitung pada saat panen.

4. Bobot kering tajuk diamati pada saat tanaman berumur $6 \mathrm{MST}$, $8 \mathrm{MST}$, dan saat panen. Pengamatan dilakukan pada 2 tanaman per petak. Bobot kering diamati dengan menimbang bagian batang dan daun setelah dikeringkan dengan oven pada suhu $80{ }^{\circ} \mathrm{C}$ selama 3 hari.

5. Warna daun dan pendugaan kandungan klorofil diamati pada 5 MST, dan 8 MST dengan menggunakan SPAD pada daun teratas yang telah membuka sempurna.

6. Pengamatan komponen hasil, yaitu jumlah anakan produktif per rumpun, panjang malai, jumlah gabah per malai, bobot 1000 butir gabah isi dengan kadar air 14\%, persentase gabah isi dan gabah hampa pada setiap malai sampel.

7. Dugaan hasil per hektar dengan menghitung produktivitas ubinan $\left(\begin{array}{lllll}1.5 & \mathrm{~m} & \mathrm{x} & 1.5 & \mathrm{~m}\end{array}\right)$ dikonversikan ke hektar.

8. Indeks panen diperoleh dari perbandingan antara bobot gabah kering dengan bobot biomas total.

Rancangan percobaan yang digunakan adalah Rancangan Kelompok Lengkap Teracak (RKLT). Penelitian ini terdiri atas satu faktor tunggal, yaitu varietas padi sawah. Faktor ini terdiri atas enam taraf varietas padi sawah, setiap taraf perlakuan diulang sebanyak tiga kali sehingga didapatkan 18 satuan percobaan. Data hasil pengamatan pertumbuhan tanaman, komponen hasil, dan hasil padi dianalisis menggunakan uji $F$ (analisis ragam), jika hasil analisis ragam menunjukkan pengaruh nyata, maka dilanjutkan dengan uji Duncan Multiple Range Test (DMRT) pada taraf 5\% (Gomez dan Gomez, 2007). Uji korelasi juga digunakan untuk mengetahui keeratan hubungan antar karakter yang diuji.

\section{HASIL DAN PEMBAHASAN}

\section{Kondisi Umum}

Curah hujan selama percobaan berkisar antara 337-511 mm bulan ${ }^{-1}$, suhu minimum (23.123.6 $\left.{ }^{\circ} \mathrm{C}\right)$ dan maksimum $\left(29.7-31.5{ }^{\circ} \mathrm{C}\right)$ dari bulan Februari 2014 - April 2014. Kisaran suhu dan kelembaban yang tinggi mendukung perkembangan hama dan penyakit seperti hawar daun terutama pada saat tanaman dalam fase vegetatif (3 MST- 8 MST). Serangan blas leher, penggerek batang, walang sangit, kepik hijau, dan hama burung muncul di awal fase reproduktif hingga fase pematangan. Suhu, radiasi surya dan curah hujan mempengaruhi hasil padi secara langsung yang melibatkan produksi gabah bernas, dan tidak langsung mendukung hama dan penyakit (Yoshida, 1981).

\section{Tinggi Tanaman}

Hasil rataan tinggi tanaman antar varietas pada saat 8 MST pada Tabel 1 menunjukkan bahwa varietas IPB 4S dan Mentik Wangi menghasilkan tinggi tanaman yang tertinggi dibandingkan varietas lainnya dengan tinggi tanaman masing-masing $102.88 \mathrm{~cm}$ dan 102.78 $\mathrm{cm}$ dan varietas dengan tinggi tanaman paling rendah dihasilkan oleh varietas Mekongga dengan tinggi tanaman $85.66 \mathrm{~cm}$. Rataan tinggi tanaman yang dihasilkan setiap varietas mendakati hasil deskripsi masing-masing varietas (Gambar 1).

Tabel 1. Nilai rataan tinggi tanaman padi pada 3 MST- 8 MST

\begin{tabular}{lllllll}
\hline \multirow{2}{*}{ Varietas } & \multicolumn{6}{c}{ Tinggi Tanaman $(\mathrm{cm})^{\mathrm{a}}$} \\
\cline { 2 - 7 } & 3 MST & 4 MST & 5 MST & 6 MST & 7 MST & 8 MST \\
\hline Inpari 13 & $52.36^{\mathrm{d}}$ & $56.73^{\mathrm{c}}$ & 63.10 & 76.11 & $82.99^{\mathrm{b}}$ & $93.72^{\mathrm{b}}$ \\
Ciherang & $51.80^{\mathrm{d}}$ & $58.26^{\mathrm{bc}}$ & 65.93 & 74.65 & $79.42^{\mathrm{b}}$ & $86.97^{\mathrm{c}}$ \\
Mekongga & $52.26^{\mathrm{d}}$ & $59.20^{\mathrm{bc}}$ & 65.91 & 74.13 & $79.47^{\mathrm{b}}$ & $85.66^{\mathrm{c}}$ \\
IPB 4S & $62.16^{\mathrm{a}}$ & $67.56^{\mathrm{a}}$ & 71.86 & 82.21 & $90.07^{\mathrm{a}}$ & $102.78^{\mathrm{a}}$ \\
Mentik Wangi & $54.50^{\mathrm{c}}$ & $62.20^{\mathrm{abc}}$ & 67.26 & 80.86 & $90.08^{\mathrm{a}}$ & $102.88^{\mathrm{a}}$ \\
Hipa Jatim 2 & $59.43^{\mathrm{b}}$ & $64.70^{\mathrm{ab}}$ & 69.93 & 78.08 & $82.43^{\mathrm{b}}$ & $90.65^{\mathrm{bc}}$ \\
\hline
\end{tabular}


Keterangan: Angka-angka yang diikuti huruf sama pada kolom yang sama tidak berbeda nyata pada Uji DMRT taraf $5 \%$

Menurut Siregar (1981) tinggi tanaman padi dibagi menjadi tiga kelompok yaitu tinggi tanaman pendek ( kurang dari $115 \mathrm{~cm}$ ), sedang $(115-125 \mathrm{~cm})$, dan tinggi (lebih dari $125 \mathrm{~cm})$. Berdasarkan hasil penelitian semua varietas termasuk kedalam varietas dengan tinggi tanaman pendek karena kurang dari $115 \mathrm{~cm}$, namun jika melihat deskripsi tanaman varietas dengan tinggi tanaman pendek adalah varietas Inpari 13, Ciherang, Mekongga. Vareietas IPB 4S, Mentik Wangi, Hipa Jatim 2 dapat dikategorikan tanaman dengan tinggi tanaman sedang dengan tinggi tanaman 114-116 cm.

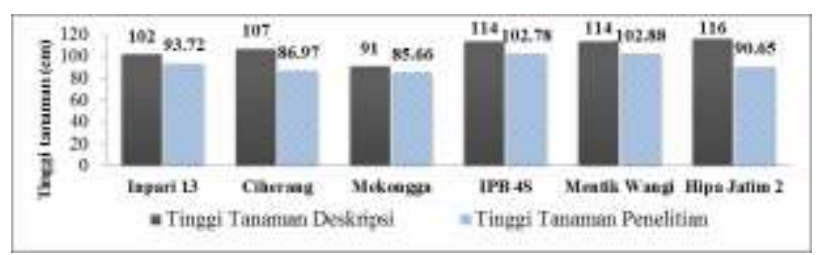

Gambar 1. Perbandingan tinggi tanaman hasil penelitian dengan tinggi tanaman deskripsi setiap Varietas

\section{Jumlah Anakan}

Hasil rataan jumlah anakan setiap varietas pada umur tanaman 8 MST menunjukkan bahwa varietas Mekongga merupakan varietas yang memiliki anakan tertinggi dengan jumlah anakan 28.30 anakan, sedangkan varietas IPB 4S merupakan varietas dengan jumlah anakan terendah yaitu 14.93 anakan. Varietas Inpari 13 dan Ciherang memiliki jumlah anakan yang nyata lebih banyak dibandingkan varietas IPB 4S, sedangkan dengan varietas Mekongga, Mentik Wangi, dan Hipa Jatim 2 memiliki jumlah anakan yang tidak berbeda nyata (Tabel 2). IPB 4S memiliki jumlah anakan sedikit sesuai dengan karakternya sebagai varietas padi tipe baru (PTB). Sifat PTB, yaitu anakan sedang (10 batang), malai panjang dengan jumlah gabah per malai banyak (250-300 butir), daun tegak, dan berumur genjah (Abdullah et al., 2009).

Menurut Atman dan Yardha (2008) pembentukan jumlah anakan produktif erat kaitannya dengan jumlah anakan maksimum yaitu semakin banyak jumlah anakan maksimum maka semakin banyak juga jumlah anakan produktifnya. Inpari 13, Ciherang dan Mekongga termasuk varietas unggul baru dan memiliki jumlah anakan yang cukup banyak. Menurut Fauziah (2014) varietas unggul baru (VUB) adalah kelompok padi yang memiliki karakteristik umur kisaran 100-135 HSS (hari setelah sebar) dan anakan banyak (lebih dari 20 tunas per rumpun). Hasil nilai rataan jumlah anakan padi menunjukkan varietas Hipa Jatim 2 termasuk varietas hibrida yang mempunyai anakan banyak (21.73 anakan) dan tidak berbeda nyata dengan varietas lokal Mentik Wangi (22.06 anakan). Suprihatno (2009) menyatakan bahwa arah penelitian padi hibrida diantaranya adalah dengan tujuan padi hibrida memiliki jumlah malai yang lebih banyak, semuanya produktif, dan jumlah gabah isi per malai seperti pada padi tipe baru.

Tabel 2. Nilai rataan jumlah anakan padi pada 3 MST- 8MST

\begin{tabular}{lllllll}
\hline \multirow{2}{*}{ Varietas } & \multicolumn{5}{c}{ Jumlah Anakan } \\
\cline { 2 - 6 } & 3 MST & 4 MST & 5 MST & 6 MST & 7 MST & 8 MST \\
\hline Inpari 13 & $14.40^{\mathrm{c}}$ & $21.66^{\mathrm{b}}$ & $25.73^{\mathrm{c}}$ & $30.86^{\mathrm{b}}$ & $26.06^{\mathrm{b}}$ & $24.70^{\mathrm{ab}}$ \\
Ciherang & $15.93^{\mathrm{b}}$ & $25.93^{\mathrm{a}}$ & $28.80^{\mathrm{ab}}$ & $33.20^{\mathrm{ab}}$ & $29.70^{\mathrm{a}}$ & $26.20^{\mathrm{ab}}$ \\
Mekongga & $16.43^{\mathrm{b}}$ & $25.86^{\mathrm{b}}$ & $28.30^{\mathrm{abc}}$ & $34.03^{\mathrm{a}}$ & $30.13^{\mathrm{a}}$ & $28.30^{\mathrm{a}}$ \\
IPB 4S & $10.33^{\mathrm{d}}$ & $14.46^{\mathrm{c}}$ & $17.36^{\mathrm{d}}$ & $19.96^{\mathrm{c}}$ & $20.60^{\mathrm{c}}$ & $14.93^{\mathrm{c}}$ \\
Mentik Wangi & $15.40^{\mathrm{bc}}$ & $23.86^{\mathrm{ab}}$ & $26.60^{\mathrm{bc}}$ & $31.20^{\mathrm{b}}$ & $25.66^{\mathrm{b}}$ & $22.06^{\mathrm{b}}$ \\
Hipa Jatim 2 & $17.96^{\mathrm{a}}$ & $25.03^{\mathrm{a}}$ & $30.40^{\mathrm{a}}$ & $32.23^{\mathrm{ab}}$ & $28.03^{\mathrm{ab}}$ & $21.73^{\mathrm{b}}$ \\
\hline
\end{tabular}

Keterangan: Angka-angka yang diikuti huruf sama pada kolom yang sama tidak berbeda nyata pada Uji DMRT taraf $5 \%$

\section{Intensitas Warna Daun}

Warna daun adalah suatu indikator yang berguna bagi kebutuhan pupuk nitrogen (N) tanaman padi. Petani umumnya menggunakan warna daun sebagai suatu indikator visual dan subjektif bagi kebutuhan tanaman padi terhadap pupuk N. Jika daun pucat atau hijau kekuningan, maka diduga terjadi defisiensi $\mathrm{N}$ pada tanaman padi tersebut. Salah satu alat yang dapat digunakan untuk mengukur tingkat kehijauan daun adalah SPAD-502. Alat ini secara digital mencatat jumlah relatif dari molekul khlorofil, sehingga sangat sensitif dan akurat (Gani, 2006).

Dobermann and Fairhurst (2000) melaporkan nilai SPAD sebesar 35 bagi daun paling atas yang telah mengembang sempurna digunakan sebagai suatu nilai batas bagi kekurangan $\mathrm{N}$ (perlu diberi $\mathrm{N}$ ) pada padi unggul yang pindah tanam. Hasil pengamatan 
menunjukkan semua varietas tidak mengalami kekurangan hara $\mathrm{N}$.

Tabel 3 menunjukkan intensitas warna daun pada pengamatan 5 MST dan 8 MST berbeda sangat nyata antar varietas. IPB $4 \mathrm{~S}$ dan Hipa Jatim 2 merupakan varietas dengan nilai SPAD tertinggi pada umur 5 MST dengan nilai masing-masing 41.13 dan 41.36, sedangkan untuk nilai SPAD terendah adalah varietas Mentik Wangi (37.67).

Tabel 3. Nilai rataan intensitas warna daun padi berdasarkan skala chlorophyll meter minolta SPAD pada MST, dan 8 MST

\begin{tabular}{lll}
\hline \multirow{2}{*}{ Varietas } & \multicolumn{2}{c}{ Nilai SPAD } \\
\cline { 2 - 3 } & $5 \mathrm{MST}$ & $8 \mathrm{MST}$ \\
\hline Inpari 13 & $39.20^{\mathrm{bc}}$ & $41.80^{\mathrm{b}}$ \\
Ciherang & $39.90^{\mathrm{b}}$ & $40.76^{\mathrm{b}}$ \\
Mekongga & $38.40^{\mathrm{cd}}$ & $40.30^{\mathrm{b}}$ \\
IPB 4S & $41.13^{\mathrm{a}}$ & $44.66^{\mathrm{a}}$ \\
Mentik Wangi & $37.67^{\mathrm{d}}$ & $37.80^{\mathrm{c}}$ \\
Hipa Jatim 2 & $41.36^{\mathrm{a}}$ & $41.66^{\mathrm{b}}$ \\
\hline
\end{tabular}

Keterangan: Angka-angka yang diikuti huruf sama pada kolom yang sama tidak berbeda nyata pada $\mathrm{Uji}$ DMRT taraf $5 \%$

Berdasarkan Tabel 3, nilai rataan intensitas daun pada 8 MST menunjukkan bahwa varietas IPB 4S memiliki nilai SPAD yang nyata lebih tinggi dibandingkan dengan varietas lainnya, yakni sebesaar 44.66 skala. Varietas Inpari 13 (41.80), Ciherang (40.76), Mekongga (40.30), dam Hipa Jatim 2 (41.66) tidak berbeda nyata satu sama lain namun berbeda nyata dengan Mentik Wangi yang menempati nilai SPAD terendah (37.80). Nilai SPAD tidak berkorelasi positif terhadap produktivitas. Hal ini di dijelaskan pula dalam penelitian Gunarsih dan Daradjat (2007) bahwa penggunaan alat SPAD untuk menduga hubungan antara intensitas warna hijau daun dengan kandungan klorofil dan kaitannya dengan produktivitas tanaman kurang tepat, terutama pada penelitian yang menggunakan bahan tanaman yang secara genetik memiliki warna daun yang relatif berbeda.

\section{Bobot Kering Tajuk}

Bobot kering tajuk antar varietas padi pada 6 MST, 8 MST dan panen tidak berbeda nyata namun nilai rataan menunjukkan bahwa terjadi penurunan bobot kering tajuk pada setiap varietas setelah 8 MST. Penelitian Simangunsong (2013) menjelaskan bahwa bobot kering tajuk antar varietas IPB 3S, Mentik Wangi, Inpari 13 dan Hipa 8 tidak berbeda nyata pada 4 MST sampai dengan tanaman berbunga, namun terjadi penumpukan asimilat pada antesis dan terjadi penurunan setelahnya hingga tanaman panen. Gambar 2 menunjukkan varietas Inpari 13, Ciherang, Mekongga, dan Mentik Wangi mengalami penurunan bobot kering tajuk pada saat panen, berbeda dengan varietas IPB $4 \mathrm{~S}$ dan Hipa Jatim 2 yang tidak mengalami penurunan bobot kering tajuk pada saat panen. Hal ini ditegaskan oleh Makarim dan Suhartik (2009) bahwa sejak inisiasi malai, terjadi penumpukan asimilat yang mencapai puncaknya pada antesis (pembungaan) dan setelah itu simpanan tersebut berkurang drastis dan berbanding terbalik dengan bobot gabah yang terus bertambah sejak antesis.

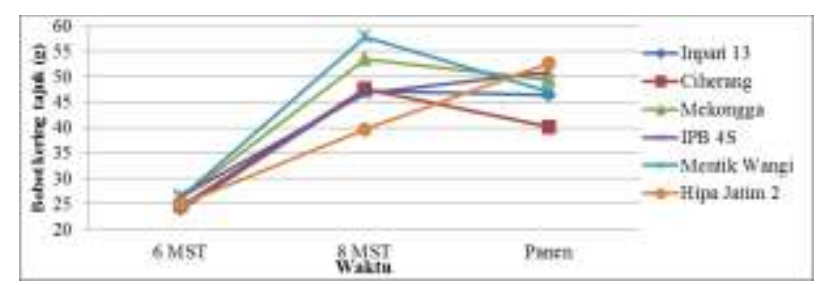

Gambar 2. Grafik rata-rata biomassa tajuk padi pada 6 MST, 8MST, dan panen

\section{Jumlah Anakan Total dan Anakan Produktif}

Kemampuan setiap varietas untuk membentuk anakan padi berbeda antar varietas yang satu dengan yang lainnya. Varietas unggul baru (VUB) seperti Inpari 13, Ciherang, Mekongga mampu membentuk anakan yang banyak dengan rataan anakan total masing-masing 17.23 anakan, 16.70 anakan dan 19.40 anakan. Padi tipe baru IPB 4S memiliki kemampuan membentuk anakan yang relatif lebih sedikit (14.76 anakan) dibandingkan varietas lokal Mentik Wangi (15.60 anakan) walaupun keduanya tidak berbeda nyata. Padi Hibrida Hipa Jatim 2 memiliki anakan yang cukup tinggi (18.23 anakan) yang tidak berbeda nyata dengan varietas Mekongga dengan jumlah anakan paling tinggi sebanyak 19.40 anakan.

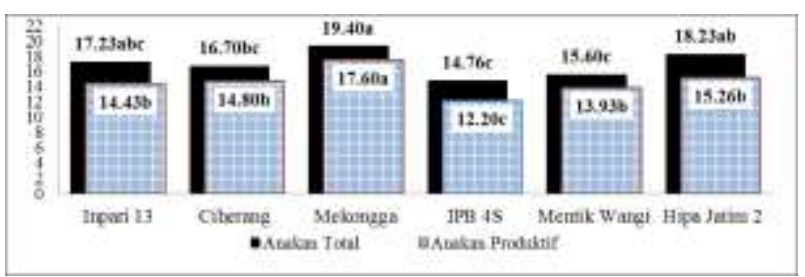

Gambar 3. Jumlah anakan maksimal dan anakan produktif

Gambar 3 menunjukkan bahwa Mekongga adalah varietas dengan anakan produktif tertinggi (17.60 anakan). Jumlah anakan 
produktif beberapa varietas tidak berbeda nyata seperti Inpari 13 (14.43 anakan), Ciherang (14.80 anakan), Mentik Wangi (13.93 anakan), dan Hipa Jatim 2 (15.26 anakan). IPB 4S adalah varietas dengan anakan produktif yang paling rendah (12.20 anakan).

\section{Komponen Hasil Padi}

Menurut Yoshida (1981) karakter tanaman yang dikaitkan dengan potensi hasil padi adalah karakter daun (tebal, pendek, tegak), batang anakan (pendek kekar), anakan (kompak, tegak, anakan banyak), dan malai (gabah isi tinggi, nisbah gabah/jerami tinggi). Hasil rataan komponen hasil menunjukkan bahwa varietas IPB $4 \mathrm{~S}$ adalah varietas dengan panjang malai terpanjang $(29.16 \mathrm{~cm})$ berbeda nyata dengan Hipa Jatim $2(26.50 \mathrm{~cm})$, Inpari $13(26.28 \mathrm{~cm})$, Mentik Wangi $(25.94 \mathrm{~cm})$, Ciherang $(24.33 \mathrm{~cm})$ dan Mekongga $(22.99 \mathrm{~cm})$. Semakin panjang rata-rata panjang malai padi maka semakin banyak jumlah gabah yang dihasilkan, namun demiian tidak selalu memberikan hasil tinggi karena dipengaruhi persentase gabah isi dan gabah hampa. Panjang malai berkolerasi positif dengan jumlah gabah per malai $(r=0.562)$ namun berkolerasi negatif dengan persentase gabah isi $(r=-0.672)$ dan bobot gabah ubinan $(\mathrm{r}=-0.644)$. IPB $4 \mathrm{~S}$ termasuk padi tipe baru yang memiliki karakter panjang malai dan jumlah gabah per malai tinggi. IPB $4 \mathrm{~S}$ menunjukkan terdapat korelasi positif antara panjang malai dengan gabah per malai $(r=0.997)$.

Tabel 4. Nilai rataan komponen hasil padi

\begin{tabular}{|c|c|c|c|c|c|}
\hline Varietas & $\begin{array}{l}\text { Panjang Malai } \\
(\mathrm{cm})\end{array}$ & $\begin{array}{c}\text { Jumlah } \\
\text { Gabah/Malai }\end{array}$ & $\begin{array}{c}\text { Gabah Isi } \\
(\%)\end{array}$ & $\begin{array}{c}\text { Gabah } \\
\text { Hampa } \\
(\%)\end{array}$ & $\begin{array}{c}\text { Bobot } \\
1000 \text { butir } \\
(\mathrm{g})\end{array}$ \\
\hline Inpari 13 & $26.28^{b}$ & $115.09^{\mathrm{abc}}$ & $72.33^{b}$ & $27.67^{\mathrm{a}}$ & 26.54 \\
\hline Ciherang & $24.33^{\mathrm{bc}}$ & $119.70^{\mathrm{ab}}$ & $83.05^{\mathrm{a}}$ & $16.94^{\mathrm{b}}$ & 28.06 \\
\hline Mekongga & $22.99^{c}$ & $92.01^{\mathrm{c}}$ & $88.73^{\mathrm{a}}$ & $11.26^{\mathrm{b}}$ & 27.93 \\
\hline IPB $4 S$ & $29.16^{\mathrm{a}}$ & $132.89^{\mathrm{a}}$ & $70.33^{\mathrm{b}}$ & $29.66^{\mathrm{a}}$ & 26.26 \\
\hline Mentik Wangi & $25.94^{\mathrm{b}}$ & $95.34 b^{c}$ & $82.77^{\mathrm{a}}$ & $17.23^{\mathrm{b}}$ & 27.08 \\
\hline Hipa Jatim 2 & $26.50^{\mathrm{b}}$ & $131.63^{\mathrm{a}}$ & $73.00^{\mathrm{b}}$ & $26.99^{\mathrm{a}}$ & 26.06 \\
\hline
\end{tabular}

Keterangan: Angka-angka yang diikuti huruf sama pada kolom yang sama tidak berbeda nyata pada Uji DMRT taraf $5 \%$

Tabel 4 menunjukkan bahwa jumlah gabah per malai varietas IPB 4S, Hipa Jatim 2, Ciherang, dan Inpari 13 tidak berbeda nyata. Jumlah gabah per malai terendah ditunjukkan oleh varietas Mekongga ( 92.01 gabah malai $^{-1}$ ) dan Mentik wangi (95.34 gabah malai $\left.{ }^{-1}\right)$. Gabah per malai berkolerasi postif dengan panjang malai $(\mathrm{r}=$ $0.562)$ namun berkolerasi negatif dengan anakan produktif $(\mathrm{r}=-0.573)$ dan persentasi gabah isi $(\mathrm{r}=$ -0.523). Suatu varietas dengan gabah per malai tinggi disertai dengan panjang malai yang tinggi akan memiliki hasil gabah kering rendah jika jumlah malai per rumpunnya rendah atau gabah isinya rendah (Abdullah, 2009).

Nilai rataan gabah isi dan gabah hampa menunjukkan bahwa varietas Mekongga, Ciherang, dan Mentik Wangi tidak berbeda nyata dan merupakan varietas dengan jumlah gabah isi tinggi diatas $80 \%$. Varietas IPB 4S,Inpari 13 dan Hipa Jatim 2 tidak berbeda nyata dan termasuk varietas dengan gabah isi rendah dibawah $75 \%$ dan gabah hampa tinggi dengan persentase 26.99\%-29.66\%. ketiga varietas ini berbeda nyata dengan varietas Mekongga, Ciherang dan Mentik Wangi. Kehampaan yang tinggi (lebih dari 20\%) disebabkan karena kemampuan tanaman menyediakan asimilat sangat terbatas, sinks yang banyak tidak terisi atau tidak termanfaatkan karena sources yang terbatas (Makarim et al., 2004). Persentase gabah isi berkorelasi negatif dengan panjang malai $(\mathrm{r}=-0.672)$ namun berkolerasi dengan bobot 1000 butir $(r=0.515)$.

\section{Hasil dan Indeks Panen Padi}

Hasil ubinan (ubinan $1.5 \mathrm{~m} \times 1.5 \mathrm{~m}$ ) dan produktivitas tertinggi dihasilkan oleh varietas Inpari 13 (1.03 kg/4.59 ton), Ciherang (1.13 $\mathrm{kg} / 4.59$ ton) dan Mekongga (1.26 kg/5.62 ton). Hasil yang tinggi pada varietas Inpari 13 diduga karena varietas ini memiliki jumlah anakan produktif yang cukup tinggi (14.43 anakan) dan gabah per malai yang cukup banyak (115.09 gabah malai $\left.{ }^{-1}\right)$. Uji korelasi pada Inpari 13 menunjukkan adanya korelasi positif antara anakan produktif dengan bobot gabah ubinan serta konversi produktivitasnya $(\mathrm{r}=1.000)$. Hasil yang tinggi pada varietas Ciherang diduga karena varietas ini memiliki anakan produktif yang cukup tinggi (14.80 anakan) dan bobot 1000 butir yang tinggi (28.06 gram) dan cukup tahan hama dan penyakit, tabel korelasi Ciherang menunjukkan 
adanya korelasi postif antara anakan produktif dengan bobot 1000 butir $(r=0.998)$. hasil yang tinggi pada varietas Mekongga diduga karena varietas ini memiliki anakan produktif tinggi (17.60 anakan), persentase gabah isi tinggi $(88.73 \%)$ dan hasil ubinan yang tinggi $(1.26 \mathrm{~kg})$ serta cukup tahan terhadap serangan hama dan penyakit.

IPB 4S merupakan varietas dengan hasil ubinan dan produktivitas terendah $(0.65 \mathrm{~kg} / 2.91$ ton) namun tidak berbeda nyata dengan Mentik Wangi $(0.83 \mathrm{~kg} / 3.71$ ton) dan Hipa Jatim 2 (0.82 $\mathrm{kg} / 3.64$ ton). Hasil yang rendah pada IPB $4 \mathrm{~S}$ diduga karena varietas ini memiliki jumlah anakan produktif rendah (12.20 anakan), kehampaan yang cukup tinggi $(29.66 \%)$ dan terserang hama dan penyakit seperti blas leher, hawar daun, wereng cokelat, dan burung. Hasil panen Mentik Wangi rendah diduga karena varietas ini mengalami kerebahan cukup tinggi pada fase pematangan pada seluruh petakannya. Menurut Yoshida (1981) tanaman rebah meyebabkan pembuluhpembuluh xylem dan floem menjadi rusak sehingga menghambat pengangkutan hara mineral dan fotosintat sehingga banyak menghasilkan gabah hampa atau kerusakan pada malai yang mengakibatkan hasil pada padi rendah. Varietas Hipa Jatim 2 adalah varietas yang mempunyai deskripsi varietas dengan hasil yang tinggi dengan rata-rata hasil 9.3 ton $\mathrm{ha}^{-1}$ dan potensi hasil 10.7 ton $\mathrm{ha}^{-1}$ namun hasil pada penelitian rendah (3.64 ton $\mathrm{ha}^{-1}$ ), hal ini diduga karena varietas ini memiliki persentase gabah isi rendah $(73.00 \%)$ dan serangan penyakit hawar daun, hama pengegerek batang dan hama burung.

Tabel 5. Hasil dan indeks panen padi

\begin{tabular}{llll}
\hline Varietas & $\begin{array}{l}\text { Hasil } \\
\text { Ubinan } \\
(\mathrm{kg})\end{array}$ & $\begin{array}{l}\text { Hasil } \\
\text { (ton GKG } \\
\text { ha }^{-1} \text { ) }\end{array}$ & $\begin{array}{l}\text { Indeks } \\
\text { Panen }\end{array}$ \\
\hline Inpari 13 & $1.03^{\mathrm{ab}}$ & $4.59^{\mathrm{ab}}$ & 0.456 \\
Ciherang & $1.13^{\mathrm{ab}}$ & $5.03^{\mathrm{ab}}$ & 0.476 \\
Mekongga & $1.26^{\mathrm{a}}$ & $5.62^{\mathrm{a}}$ & 0.470 \\
IPB 4S & $0.65^{\mathrm{c}}$ & $2.91^{\mathrm{c}}$ & 0.423 \\
Mentik Wangi & $0.83^{\mathrm{bc}}$ & $3.71^{\mathrm{bc}}$ & 0.420 \\
Hipa Jatim 2 & $0.82^{\mathrm{bc}}$ & $3.64^{\mathrm{bc}}$ & 0.453 \\
\hline Keterangan: & Angka-angka yang diikuti huruf sama pada \\
\multicolumn{4}{c}{ kolom yang sama tidak berbeda nyata pada Uji } \\
\multicolumn{4}{c}{ DMRT taraf 5 \% }
\end{tabular}

Indeks panen merupakan rasio bobot gabah dengan total biomas. Hasil dapat ditingkatkan dengan meningkatkan indeks hasil atau meningkatkan produksi bahan kering total (Zapata, 1983). Tabel 5 menunjukkan indeks panen semua varietas tidak berbeda nyata (berada Evaluasi Produktivitas Beberapa..... pada kisaran 0.420 - 0.476). hasil indeks panen semua varietas mendekati nilai rataan indeks hasil varietas-varietas unggul. indeks hasil rata-rata untuk varietas-varietas unggul adalah 0.5 (Makarim dan Suhartatik, 2009). Indeks panen ini sangat dipengaruhi oleh bobot gabah dengan total biomas yang diperoleh oleh masing-masing varietas.

\section{KESIMPULAN}

Hasil penelitian menunjukkan bahwa produktivitas varietas unggul baru (VUB) Inpari 13, Ciherang dan Mekongga berkisar antara 4.59 hingga 5.62 ton $\mathrm{ha}^{-1}$. Secara umum, hasil produktivitas ketiga VUB ini dipengaruhi oleh anakan produktif, bobot 1000 butir, persentase gabah isi dan ketahanan terhadap hama penyakit. IPB 4S memiliki potensi hasil yang tinggi (10.50 ton $\mathrm{ha}^{-1}$ ) dengan keunggulan memiliki panjang malai dan jumlah gabah per malai yang tinggi namun hasil produktivitas masih rendah karena terserang wereng cokelat, burung, dan blas leher serta anakan rendah dan gabah hampa yang tinggi. Hasil produktivitas varietas Mentik Wangi dipengaruhi oleh panjang malai, bobot 1000 butir dan persentase gabah isi yang tinggi, kerebahan yang tinggi menyebabkan hasil produktivitasnya rendah. Hasil produktivitas Hipa Jatim 2 rendah karena hasil penelitian menunjukkan varietas ini tidak tahan serangan penyakit hawar daun, hama pengegerek batang dan hama burung dan varietas ini memiliki persentase gabah isi rendah.

\section{DAFTAR PUSTAKA}

Abdullah, B. 2009. Perakitan dan Pengembangan Varietas Padi Tipe Baru [Internet]. [diunduh 2014 Sep 23]. Tersedia pada: http://www.litbang.deptan.go.id / special / padi / bbpadi_2009_itp_03.pdf.

Atman, Yardha. 2008. Pengaruh Jumlah Bibit Terhadap Pertumbuhan dan Hasil Padi Sawah Varietas Batang Lembang [Internet]. [diunduh 2014 Okt 22]. Tersedia pada: http://digilib.litbang.deptan.go.id/ jambi/ge tiptan.php?src=2008/pros53r.pdf\&format=a pplication/pdf.

[BPS] Badan Pusat Statistik. 2013. Tabel Luas Panen Produktivitas Tanaman Padi Seluruh Provinsi [Internet]. [diunduh 2013 Nov 26]. Tersedia pada: http://www.bps.go.id /tnmn_pgn.php. 
[BPS] Badan Pusat Statistik. 2014. Laporan Bulanan Data Sosial Ekonomi. Jakarta (ID): Badan Pusat Statistik.

[Deptan] Departemen Pertanian. 2011. Laporan Kinerja Kementerian Pertanian Tahun 2011 [Internet]. [diunduh 2013 Nov 26]. Tersedia pada:http://www.litbang.deptan.go.id/speci al/padi/bbpadi_2009_itkp_11.pdf.

[Deptan] Departemen Pertanian. 2013. Kebijakan Dan Rekomendasi Pengembangan Diversifikasi Pangan (Suatu Program Aksi) [Internet]. [diunduh 2014 Okt 21]. Tersedia pada:http://pascapanen.litbang.Deptan.go.id /assets/media/berita/KEBIJAKAN_DAN_R EKOMENDASI_PENGEMBANGAN_DI VERSIFIKASI_PANGAN.pdf.

Dobermann, A, Fairhurst, T. 2000. Rice : Nutrient Disordes and Nutrient Management. Canada (US): Potash and Phospate Institute.

Fauziah, A. 2014. Pengembangan Benih dan Varietas Unggul Padi Sawah [Internet]. [diunduh 2014 Sep 23]. Tersedia pada: http://cybex.deptan.go.id/lokalita/pengemba ngan-benih-dan-varietasunggul-padi-sawaholeh-ir-hj-fauziah.

Gani, A. 2006. Bagan Warna Daun [Internet]. [diunduh 2014 Sep 21]. Tersedia pada: http://www.dpi.nsw.gov.au/_data/assets/p df_file/0008/199457/Ses3-Leaf-colourchart.pdf.

Gomez, K.A., Gomez, A.A. 2007. Prosedur Statistik untuk Penelitian Pertanian. Edisi II. Sjamsuddin, E., Baharsjah, J.S., penerjemah. Jakarta (ID): UI pr. Terjemah dari : Statistical Procedures for Agricultural Research.

Gunarsih, A., Daradjat, A.A. 2007. Viabilitas Kecepatan Senesens pada Sejumlah Genotipe Padi Sawah serta Korelasinya dengan Hasil dan Komponen Hasil [Internet]. [diunduh 2014 Sep 21]. Tersedia pada: http://www.litbang.deptan.go.id /special/padi/ bbpadi_2008_p2bn2_03.pdf.
Las, I., Widiarta, I.N., Suprihatno, B. 2004. Perkembangan varietas dalam perpadian nasional. Dalam: Makarim, A.K., editor. Inovasi Pertanian Tanaman Pangan. Bogor (ID): Pusat Penelitian dan Pengembangan Tanaman Pangan. hlm 1-25.

Makarim, A.K., Las, A.M., Fagi, Widiarta, I.N., Pasaribu, D. 2004. Padi Tipe Baru: Budidaya dengan Pendekatan Pengelolaan Tanaman Terpadu. Subang (ID). Balai Penelitian Tanaman Padi Sukamandi.

Makarim, A.K., Suhartik, E. 2009. Morfologi dan Fisiologi Tanaman Padi [Internet].

Miah, M.N.H., Yoshida, T., Yamamoto, Y., Nitta, Y. 1996. Characteristics of dry matter production and partitioning of dry matter in yielding semi dwarf indica and japonicaindica hybrid rice varieties. J.Crop Sci. 65:672-685.

Minarsih, A., Prayudi, B., Warsito. 2013. Keragaan beberapa varietas unggul baru padi sawah irigasi dengan menerapkan pengelolaan tanaman terpadu (PTT) di Kabupaten Klaten. Seminar Nasional : Menggagas Kebangkitan Komoditas Unggulan Lokal Pertanian dan Kelautan Fakultas Pertanian Universitas Trunojoyo Madura; 2013 Juni [tanggal tidak jelas]; Madura, Indonesia. Madura (ID). Balai Pengkajian Teknologi Pertanian Jawa Tengah. hlm 582-587

Sembiring, H. 2007. Kebijakan penelitian dan rangkuman hasil penelitian BB Padi dalam mendukung peningkatan produksi beras nasional. Apresiasi Hasil Penelitian Padi [Internet]. [diunduh 2014 Okt 22]: 39-59. Tersedia pada: www.litbang.deptan.go.id /special/padi/bbpadi_2008_p2bn1_03.pdf.

Simangunsong, M. 2013. Analisis produktivitas beberapa tipe padi [skripsi]. Bogor (ID): Institut Pertanian Bogor.

Siregar, H. 1981. Budidaya Tanaman Padi di Indonesia. Jakarta (ID): Sastra Hudaya.

Suprihatno, B., Dradjat, A.A., Satoto, Baehaki, Widiarta, I.N., Setyono, A., Indrasari, S.D., Lesmana, O.S., Sembiring, H. 2009. Deskripsi Varietas Padi. Subang (ID). Balai Besar Penelitian Padi Sukamandi. 
Suprihatno, B. 2009. Peta jalan perakitan dan pengembangan varietas unggul hibrida tipe baru menuju sistem produksi padi berkelanjutan. Pengembangan Inovasi Pertanian 2(1):1-13.

Yoshida, S. 1981. Fundamental of Rice Crop Science. Los Banos (PH): International Rice Research Institute.
Zapata, F.J. 1983. Rice Anther Culture at IRRI. In Cell and Tissue Culture Techniques for Cereal Crop Improvement. Beijing $(\mathrm{CH})$ : Science Press.

Zein, S., Zarwan, Bahar, H. 2002. Parameter genetik karakter agronomi padi gogo. Stigma 10(3): 208-213. 